\title{
Benign Bladder Neoplasm
}

National Cancer Institute

\section{Source}

National Cancer Institute. Benign Bladder Neoplasm. NCI Thesaurus. Code C3618.

A non-metastasizing neoplasm that arises from the bladder. 